\title{
Penghematan Air di Hotel X Kota Batam Provinsi Kepulauan Riau dengan Menerapkan Daur Ulang Air Limbah
}

\author{
Rio Andi Suhandi ${ }^{1}$, Eka Wardhani ${ }^{2}$ \\ ${ }^{1,2}$ Teknik Lingkungan, Institut Teknologi Nasional, Bandung \\ *Koresponden email: rioandisuhandi46@gmail.com
}

Diterima: 12 Juni 2021

Disetujui: 25 Juni 2021

\begin{abstract}
Hotel $\mathrm{X}$ is a hotel located in the city of Batam, the province of the Riau Islands, which is expected to be visited by tourists on holiday in the city of Batam. As the main means of providing comfort and health to guests, Hotel X should plan a good clean water supply system in terms of quality, quantity, and continuity. Currently available clean water sources are limited, such that sufficient efforts must be made to recycle clean water. This research aims to plan water savings at Hotel X using the Green Building concept in the aspect of water conservation. The concept of this research is to recycling greywater into a second quality water source that can be used for rinsing and sprinkling water. Calculating of water requirements, generation of grey water wastewater refers to the Regulation of the 2017 Minister of Public Works and Public Housing Regulation, No. 4, Domestic Wastewater Management System. The greywater recycling process is conducted using biological and chemical processes. Based on the research use of recycled water research has the potential to conserve water use amounted to $200.32 \mathrm{~m}^{3} /$ day of total water use of $313 \mathrm{~m}^{3} /$ day or the percentage of water savings of $64 \%$.
\end{abstract}

Keywords: hotel, water-saving, recycling, water conservation, wastewater

\section{Abstrak}

Hotel X merupakan sebuah hotel yang berada di Kota Batam Provinsi Kepulauan Riau, yang diharapkan dapat dikunjungi oleh para wisatawan yang berlibur di Kota Batam. Sebagai sarana utama untuk memberikan kenyamanan dan kesehatan pada tamu maka Hotel X haruslah merencanakan sistem penyediaan air bersih yang baik dari segi kualitas, kuantitas, dan kontinuitas. Saat ini sumber air bersih tersedia terbatas sehingga untuk memenuhinya harus ada upaya untuk mendaur ulang air bersih. Penelitian ini bertujuan merencanakan penghematan air di Hotel X menggunakan konsep green building pada aspek konservasi air. Konsep yang diterapkan pada penelitian ini yaitu daur ulang grey water untuk dijadikan sumber air kualitas kedua yang dapat digunakan untuk penggelontoran dan penyiraman air. Perhitungan kebutuhan air, timbulan air limbah grey water mengacu pada Peraturan Menteri pekerjaan Umum dan Perumahan Rakyat Nomor 4 Tahun 2017 sistem pengelolaan air limbah domestik. Proses daur ulang grey water dilakukan dengan menggunakan proses biologi dan kimia. Berdasarkan hasil penelitian penggunaan daur ulang air bersih berpotensi menghemat penggunaan air sebesar $200,32 \mathrm{~m}^{3} /$ hari dari total penggunaan air bersih sebesar $313 \mathrm{~m}^{3} /$ hari atau presentase penghematan air sebesar $64 \%$.

Kata Kunci: hotel, daur ulang, penghematan, konservasi air, air limbah

\section{Pendahuluan}

Hotel merupakan jenis akomodasi yang digunakan sebagai jasa pelayanan, penginapan, makanan, dan minuman serta jasa yang lainnya. Hotel dikelola secara komersial untuk masyarakat umum yang ingin menginap [1]. Kota Batam merupakan salah satu kota yang berada di Kepulauan Riau dan merupakan kota terbesar di Kepulauan Riau. Kota Batam memiliki jalur pelayaran internasional sehingga memiliki wilayah yang strategis karena kota ini mempunyai jarak yang dekat serta berbatasan eksklusif dengan negara wisata Asia yaitu Singapura dan Malaysia [2]. Hal ini menjadi pemasukan ekonomi yang besar bagi Kota Batam sebab banyak wisatawan dalam negeri maupun mancanegara yang berkunjung ke Kota Batam. Peningkatan pendapatan berasal dari wisatawan yang berkunjung ke Kota Batam [2]. Kenaikan jumlah wisatawan yang terjadi harus diiringi dengan peningkatan fasilitas penunjangnya diantaranya hotel dengan fasilitas yang memadai [2]. Hotel X direncanakan akan dibangun di Kota Batam Provinsi Kepulauan Riau [3]. Hotel ini merupakan hotel bintang empat yang terdiri dari halaman utama, lobby, area parkir yang luas, operator, ballroom, dapur, ruang spa, dapur, berbagai jenis kamar dengan jumlahnya 402 kamar dan fasilitas lainnya. Hotel X memiliki berbagai jenis-jenis kamar seperti Standard room, Deluxe Room 1, Deluxe Room 2, Small room, Junior Suite Room, Suite Room, Presidential Suite Room [3]. Salah satu cara untuk memberi 
kenyamanan dan menjamin kesehatan pengguna maka hotel $\mathrm{X}$ harus menyediakan air bersih yang terjamin dari segi kualitas, kuantitas, dan kontinuitas [1] [4].

Saat ini ketersediaan air bersih di Kota Batam sangat terbatas sebab kota ini tidak mempunyai sumber daya daya air yang banyak dan cukup rentan mengalami kekeringan [5]. Berdasarkan perhitungan tahun 2015 kebutuhan air higienis domestik Kota Batam diprediksi sebanyak 4.588,85 liter/dtk serta kapasitas desain produksi Water Treatment Plant (WTP) Kota Batam di tahun yang sama sebesar 4.682 liter/dtk. Berdasarkan perbandingan kebutuhan dan kapasitas desain produksi WTP disimpulkan hanya bisa mencukupi kebutuhan air bersih Kota Batam sampai akhir tahun 2015. Proyeksi kebutuhan air domestik pada tahun 2025 diperkirakan sebesar 9.279,15 liter/dtk, sebagai akibatnya terjadi kekurangan air sebanyak 4.597,15 liter/dtk berasal kapasitas desain produksi waktu ini [6]. PDAM Kota Batam akan memprioritaskan pelayanan air bersih untuk keperluan domestik. Air baku yang ada hanya mengandalkan curah hujan yang ditampung di lima waduk yang dibuat oleh Otoritas Batam (BP Batam). Waduk Duriangkang jadi tulang punggung menopang 70 persen kebutuhan air bagi warga Batam. Kurangnya sumber air standar membuat pemerintah melalui BP Batam sangat menjaga ketersediaan air baku. Keberadaan waduk di Batam tidak dapat digunakan untuk kepentingan lain, apalagi dapat mempengaruhi kualitas air ataupun mengganggu fungsi catchment area [5].

Pembangunan Hotel X memerlukan jumlah air yang cukup banyak sehingga sebagai langkah untuk penghematan air dan menjaga keberlangsungan ketersediaan air di Kota Batam maka dalam penyediaan air bersih Hotel X akan menerapkan konsep Green Building [4]. Penerapan konsep Green Building dimulai sejak tahapan perencanaan, pembangunan, pengoperasian hingga dalam operasional pemeliharaannya memperhatikan aspek-aspek pada melindungi, menghemat, mengurangi penggunaan asal daya alam [7]. Konsep Green Building terdiri dari 6 kategori yaitu pengurangan penggunaan air, penggunaan alat plumbing hemat air, daur ulang air limbah baik black maupun grey water, penggunaan sumber air alternatif seperti air hujan dan air bekas wudhu, penampungan air, dan efisiensi penggunaan air lanskap [7].

Hotel $\mathrm{X}$ akan menerapkan konsep aspek konservasi air dengan cara daur ulang grey water yang dihasilkan aktifitas di dalam hotel untuk diolah menjadi air kualitas dua (second class). Air kualitas kedua ini dipergunakan untuk penggelontoran water closet, urinoir, dan penyiraman tanaman yang tidak memerlukan kualitas air terbaik. Penerapan daur ulang grey water ini didukung dengan perencanaan perpipaan air limbah yang terpisah antara grey dan black water di Hotel X. Grey water akan di daur ulang dan black water yang telah terkumpul akan diolah di tangki septik dan bidang resapan dimana lumpur yang dihasilkan akan diserahkan ke pihak ketiga berizin dan effluent tangki septik dibuang ke badan air penerima terdekat. Tujuan melakukan daur ulang ini untuk dapat mengurangi penggunaan air bersih. Hasil penelitian ini diharapkan menjawab pertanyaan berapa jumlah air yang dapat di hemat dengan penerapan daur ulang grey water.

Penerapan konsep green building telah dilakukan di beberapa lokasi pembangunan gedung seperti perencanaan Sistem Plambing Air Limbah dengan Penerapan Konsep Green Building pada Gedung Panghegar Resort Dago Golf-Hotel danSpa [8], Perencanaan Sistem Instalasi Plambing Air Bersih dengan Penerapan Alat Plambing Hemat Air Di Rumah Sakit Universitas Sam Ratulangi [9], Implementasi konsep konservasi air di Gedung Apartemen X [10], dan Perencanaan Konsep Konservasi Air Gedung Universitas Swasta di Wilayah Utara Kota Bandung [11].

\section{Metode Perencanaan}

Perencanaan sistem plambing pada pembangunan Hotel X ini dilakukan dengan urutan pekerjaan dimulai tahap persiapan, yang terdiri dari pencarian studi literatur mengenai teori-teori yang diperlukan dalam penelitian ini meliputi proses daur ulang, pengolahan air dan standar yang digunakan dalam perencanaan dan peraturan-peraturan yang terkait. Standar dan peraturan dalam penelitian SNI-03-70652005 tentang Tata Cara Perencanaan Sistem Plambing dan SNI-8153-2015 tentang Sistem Plambing pada Bangunan Gedung). Data sekunder yang dikumpulkan meliputi denah hotel yang berfungsi untuk merencanakan sistem plambing air bersih serta fungsi dan luasan tiap lantai yang berfungsi untuk menghitung jumlah populasi yang ada di dalam bangunan.

Perhitungan jumlah populasi tiap lantai di Hotel X menggunakan persamaan 1, luas efektif di Hotel $\mathrm{X}$ diperoleh dari luas keseluruhan ruangan dikalikan dengan $80 \%$ menurut sehingga hasil dari perkalian tersebut didapatkan luas efektif. Selanjutnya setelah didapatkan luasan efektif maka hasil tersebut dibagi dengan beban hunian. Beban hunian ini ialah berapakah jumlah orang yang dapat ditampung di dalam satu lantai atau ruangan, beban hunian haruslah dipengaruhi dengan mempertimbangkan kegunaan atau fungsi bangunan, letak lantai tersebut [12][13]. 
Jumlah Populasi (orang) $=\frac{\text { Luas ef ektif }(\%) \text { x luas ruangan }(m 2)}{\text { Beban hunian }}$

Perhitungan kebutuhan air higienis dihitung menggunakan menggunakan persamaan 2 [12],[13]. Kebutuhan air higienis dapat ditentukan dengan mengalikan jumlah populasi dengan standar pemakaian air [12], [13].

Kebutuhan Air bersih/Qam (Liter/Hari) = Jumlah populasi x Standar pemakaian air bersih

Perhitungan debit air buangan disajikan pada persamaan 3, dimana rasio air buangan yang dihasilkan sebesar $80 \%$ dari total kebutuhan air bersih [14].

Debit air buangan Qab (L/hari) $=80 \%$ x Jumlah total kebutuhan air bersih

Perhitungan debit grey water, dilakukan dengan cara mengkalikan debit air limbah yang dihasilkan dengan rasio timbulan air limbah grey water. Presentase grey water yang dihasilkan sebesar $20 \%$ dari total timbulan air limbah [15]. Rumus disajikan pada persamaan 4.

Q grey water $=\mathrm{Q}$ air buangan $\mathrm{x} 20 \%$

Pengolahan limbah grey water merupakan salah satu aspek konservasi air [7], perencanaan instalasi pengolahan grey water dengan menggunakan STP (Sewage Treatment Plant). Perencanaan STP terdiri dari penentuan kapasitas pengolahan, jenis unit pengolahan, serta menghitung efisiensi yang didapatkan dengan rumus disajikan pada persamaan 5 .

$$
\text { Efisiensi }=\frac{\text { Total air daur ulang }}{\text { Total kebutuhan air daur ulang }} \times 100 \%
$$

\section{Hasil dan Pembahasan}

Hotel X akan akan terdiri dari bangunan dengan 23 lantai dan memiliki tambahan rooftop di atasnya, dengan luas lahan sebesar seluas 3.263,28 $\mathrm{m}^{2}$. Hotel X memliki berbagai fasilitas yang dapat menunjang kenyaman bagi pengunjung [3]. Selain memiliki fasilitas pendukung Hotel X memiliki berbagai jenis kamar dengan jumlah 402 unit. Perbedaan jenis kamar di hotel ini berdasarkan ukuran luas dari setiap kamar. Kamar-kamar tersebut yaitu Standard room, Deluxe Room 1, Deluxe Room 2, Small room, Junior Suite Room, Suite Room, Presidential Suite Room [3]. Alat sanitasi/plambing yang digunakan di setiap kamar dari Hotel X adalah water kloset, lavatory, jet spray, dan shower [3].

Sumber air bersih Hotel X berasal dari PDAM PT. Adhya Tirta Batam sementara pengaliran air menggunakan ground water tank dan rooftank. Aliran air dari PDAM dialirkan menuju ground water tank 1 untuk ditampung, lalu kemudian dipompakan menuju roof tank 1 kemudian dialirkan ke masing-masing alat plambing yang ada di hotel ini seperti lavatory, jet spray, faucet, dan shower. Air daur ulang second class yang berasal dari proses pengolahan air grey water di tampung di ground water tank 2, lalu kemudian dipompakan menuju roof tank 2 kemudian di alirkan ke alat plambing WC sebagai flushing. Skematik diagram air bersih seperti disajikan pada Gambar 1.

Kebutuhan air bersih di Hotel X dihitung dengan terlebih dahulu mengetahui data jumlah populasi yang ada di dalam hotel. Setelah mengetahui populasi yang terdapat di Hotel X, populasi tersebut dikalikan dengan kebutuhan air bersih [16]. Jenis gedung peruntukan hotel pemakaian air pengunjung 300 L/orang/hari, karyawan 50 L/orang/hari [16]. Perhitungan kebutuhan air di Hotel X menggunakan safety factor, yang memiliki fungsi untuk menjaga kesediaan air bersih yang ada di dalam Hotel X jika sewaktuwaktu terjadi lonjakan pengunjung dan penggunaan air bersih. Angka yang dipergunakan sebesar $20 \%$ dari total kebutuhan air. Air bersih di Hotel X akan digunakan untuk kegiatan sehari-hari seperti, mandi, memasak dan lain-lain seperti disajikan pada Tabel 1. 


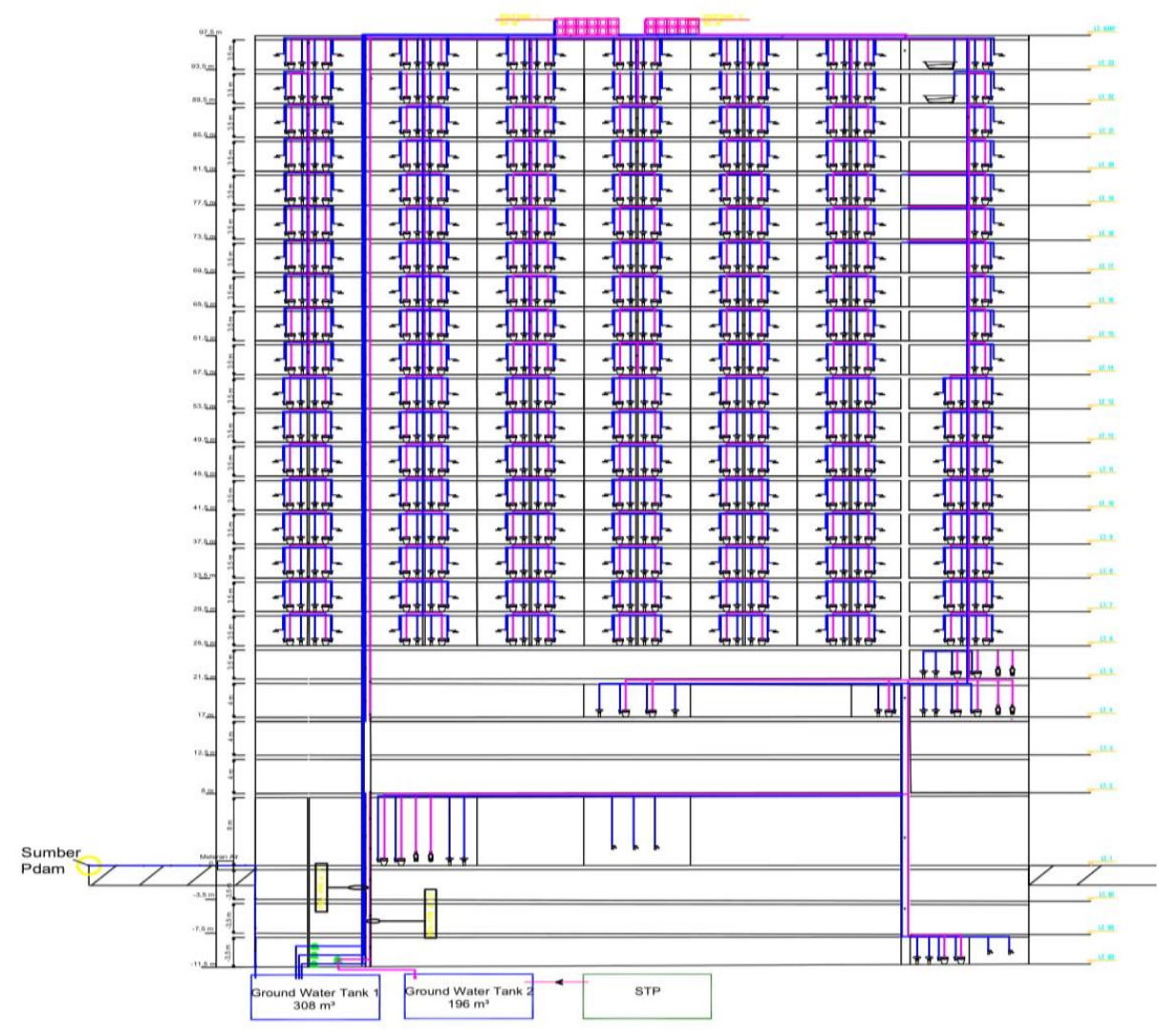

Gambar 1. Skematik diagram air bersih Sumber: Hasil perencanaan, 2021

Tabel 1. Rekapitulasi kebutuhan air bersih

\begin{tabular}{lccrr}
\hline \multicolumn{1}{c}{ Jenis } & $\begin{array}{c}\text { Jumlah Populasi } \\
\text { orang }\end{array}$ & $\begin{array}{c}\text { Kebutuhan air } \\
\text { l/orang/hari }\end{array}$ & $\begin{array}{c}\text { Total } \\
\text { l/hari }\end{array}$ & $\begin{array}{c}\text { Total } \\
\mathrm{m}^{3} / \mathrm{hari}^{2}\end{array}$ \\
\hline Penghuni dan Pengunjung & 898 & 300 & 252.344 & 252 \\
Karyawan & 176 & 50 & 8.798 & 8,80 \\
Total & & & 261.142 & 261 \\
Safety Factor 20\% & & & & 52 \\
\hline Total kebutuhan air bersih Hotel X & & & 313 \\
\hline
\end{tabular}

Sunber: Perhitungan, 2021

Air buangan (grey water) yang dihasilkan di Hotel X akan digunakan kembali menjadi air bersih second class, maka air ini harus terlebih dahulu pengolahan terlebih dahulu dengan jenis Sewage Treatment Plant (STP) yang dapat menghasilkan kualitas sumber air daur ulang sesuai dengan baku mutu yang diperbolehkan pemerintah. Perhitungan debit air buangan, yang dihasilkan sebesar $80 \%$ dari total kebutuhan air bersih sehingga total timbulan air limbah yang dihasilkan sebesar $250,4 \mathrm{~m}^{3} /$ hari. Grey water yang dihasilkan akan diolah dengan menggunakan STP. Pengolahan dalam STP ditargetkan menghasilkan kualitas sumber air sesuai dengan Peraturan Pemerintahan Republik Indonesia Nomor 22 Tahun 2021 Tentang Penyelenggaraan Perlindungan dan Pengelolaan Lingkungan Hidup kelas IV [17]. Menurut peraturan tersebut, air yang peruntukannya dapat digunakan untuk mengairi pertanaman, dan atau peruntukan lain yang mempersyaratkan mutu air yang sama dengan kegunaan tersebut. Air buangan yang sudah diolah dapat digunakan sebagai air untuk untuk mengairi tanaman dan atau untuk peruntukan lain seperti flushing yang mempersyaratkan mutu air yang sama dengan kegunaan tersebut. Berikut ini merupakan tabel dari perbandingan hasil buangan dengan baku mutu Permen LH Nomor 5 Tentang Baku Mutu Air Limbah Tahun 2014 dan baku mutu PP nomor 22 tahun 2021 [18]. Tabel 2 menyajikan perbandingan karakteristik air hasil olahan dengan baku mutu. Karakteristik air hasil olahan menggunakan hasil penelitian sejenis di hotel yang ada di Kota Bandung [19]. 
Tabel 2. Perbandingan karakteristik air hasil olahan dengan baku mutu

\begin{tabular}{cccc}
\hline No & Parameter & Hasil Air Buangan $(\mathrm{mg} / \mathrm{L})^{(* 1)}$ & Kualitas Air Buangan $(\mathrm{mg} / \mathrm{L})^{(* 2)}$ \\
\hline 1. & BOD & 115 & 100 \\
2. & COD & 128 & - \\
3. & Minyak dan lemak & 73,5 & 10 \\
4. & TSS & 4.896 & 100 \\
5. & pH & 7,06 & $6-9$ \\
\hline
\end{tabular}

Keterangan: ${ }^{1}[19]^{2}[18]$

Tahapan-tahapan pengolahan air menggunakan proses biologi dengan tahapan terdiri dari penyaringan, ekualisasi, pengolahan biologi dengan sistem anaerobik dan aerobik. Hasil pengolahan biologi diendapkan di tangki sedimentasi. Langkah untuk menyisihkan mikroorganisme pathogen menggunakan proses klorinasi. Lumpur yang dihasilkan diolah di unit pengolahan lumpur dan akan diserahkan ke pihak ketiga berizin untuk ditangani sesuai dengan peraturan yang berlaku seperti disajikan pada Gambar 2. Pengolahan air limbah dengan menggunakan proses biologi telah diterapakan di Hotel Aston Braga City Walk [19], Mal X Kota Bandung [20], Gedung Rusunawa Mahasiswa Universitas Andalas [21], INBIS Permata Bunda, Bontang [22], dan Universitas Andalas Limau Manis Padang [23]. Berdasarkan hasil penelitian tersebut diperoleh hasil yang sesuai dengan baku mutu yang ditetapkan.

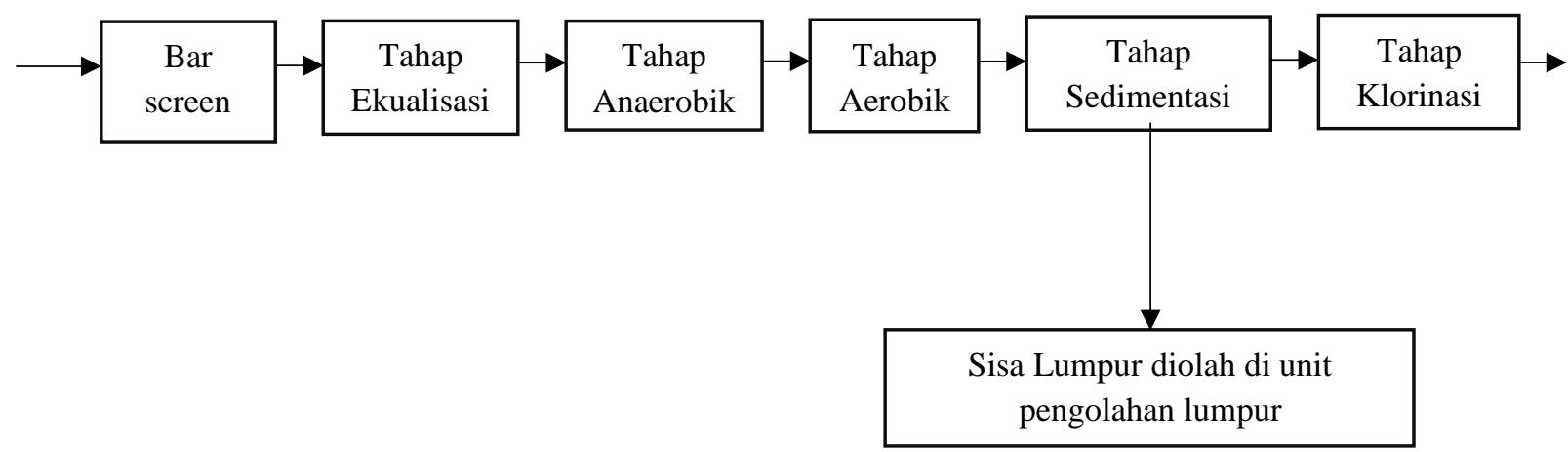

Gambar 2. Tahapan pengolahan grey water di Hotel X Sumber: Hasil perencanaan, 2021

Proses pengolahan fisik merupakan pengolahan yang melibatkan proses fisik, pengolahan ini bertujuan untuk menghilangkan padatan tersuspensi dan minyak dalam aliran air limbah. Tahapan yang dapat digunakan untuk pengolahan fisik ialah saringan (bar screen) dan ekualisasi [24]. Tujuan penyaringan ialah memisahkan kotoran-kotoran yang berupa zat padat kasar dan berukuran relatif besar yang terdapat dalam air limbah. Saringan bisa berupa kawat-kawat, kisi-kisi, kawat kasar, maupun plat berlubang [24]. Air limbah domestik yang berasal dari toilet akan masuk ke tangki ekualiasasi terlebih dahulu. Tangki ekualisasi telah dilengkapi dengan grease trap dan screen yang berfungsi untuk memisahkan air limbah dari lemak, minyak dan sampah padat. Selain itu tangki ini berfungsi untuk meratakan kualitas air limbah dan siap untuk dialirkan ke tahap aerasi [24]

Proses pengolahan biologi bertujuan untuk menghilangkan dan menstabilkan zat-zat pencemar organik terlarut yang dilaksanakan oleh jasad renik dari limbah cair. Tahapan yang dapat digunakan untuk pengolahan biologi ialah tahap aerob, tahap anaerob dan sedimentasi [24]. Pengolahan biologi secara anaerobik pada tangki ini berarti penguraian partikel organik oleh mikroorganisme tanpa menggunakan oksigen. Proses pengolahan secara aerobik pada tangki ini berarti akan terjadi penguraian partikel organik oleh mikroorganisme pengurai secara aerob dengan bantuan mesin penambah udara. Pada tahap ini dilengkapi dengan media sel yaitu media yang didesain khusus untuk pertumbuhan mikroorganisme. Tangki Sedimentasi, lumpur atau biomassa yang lolos akan mengendap di dasar tangki sedimentasi. Pada tangki ini akan terjadi proses pemisahan lumpur dengan air limbah dengan media honeycom hexagonal [24].

Proses pengolahan kimia bertujuan untuk menghilangkan atau mengubah senyawa pencemar dalam air limbah dengan menambahkan bahan kimia. Proses pengolahan kimia harus ditambahi klor untuk memusnahkan mikroorganisme pathogen. Tahapan yang dapat digunakan untuk pengolahan biologi ialah klorinasi. Tangki klorinasi, pada bak khlorinasi ini air limbah direaksikan dengan senyawa khlor untuk membunuh senyawa mikroorganisme patogen [24]. 
Efisiensi pengolahan adalah sasaran yang wajib dipenuhi unit pengolah agar efluen tidak mencemari badan air penerima. Efisiensi pengolahan dihitung dengan mengurangi nilai konsentrasi yang masuk menggunakan standar mutu dibagi menggunakan konsentrasi yang masuk [24]. Efisiensi penyisihan dapat dilihat pada Tabel 3.

Tabel 3. Efisiensi penyisihan unit pengolahan

\begin{tabular}{ccc}
\hline Unit Pengolahan & Efisiensi Penyisihan & Referensi \\
\hline Bar screen & Suspended Solid $(5-30 \%)$ & [24] \\
Tangki Ekualisasi & Minyak/lemak $(70-90)$ & \\
Pengolahan biologi secara & BOD $(60-70 \%)$ \\
anaerobik & COD $(60-70 \%)$ \\
& Suspended Solid $(80-95 \%)$ & [4] \\
Pengolahan biologi secara Aerobik & BOD $(75-95 \%)$ & \\
Tangki Sedimentasi & COD $(80-85 \%)$ & \\
& Suspended Solid $(50-65 \%)$ & \\
Tangki Klorinasi & COD $(30-40 \%)$ & \\
\hline Sumber: ${ }^{4)}$ Metcalf \& Edddy.2003. ${ }^{24)}$ Tchobanoglous.2014
\end{tabular}

Setelah mendapatkan efisiensi penyisihan dari setiap unit pengolahan maka selanjutnya hasil air buangan tersebut dikalikan dengan persentase efisiensi dari unit tersebut maka didapatkan parameter air buangan setelah diolah tersebut. Hasil air buangan air buangan dapat dilihat pada Tabel 4.

Tabel 4. Hasil air buangan setelah pengolahan

\begin{tabular}{cccc}
\hline No & Parameter & Hasil Air Buangan $(\mathrm{mg} / \mathrm{L})^{(19)}$ & Air Buangan Setelah Pengolahan $^{(2)}$ \\
\hline 1. & BOD & 115 & 16 \\
2. & COD & 128 & 18 \\
3. & Minyak dan lemak & 73,5 & 51,5 \\
4. & TSS & 4.896 & 49 \\
5. & pH & 7,06 & 7 \\
\hline
\end{tabular}

Keterangan: ${ }^{19)}$ Sitompul,2013 ${ }^{2)}$ Hasil perhitungan, 2021

Air buangan yang sudah selesai di daur ulang menggunakan dapat digunakan kembali sebagai air bersih second class. Setelah melakukan perhitungan, didapatkan jumlah timbulan air buangan di Hotel X sebesar 250,4 m³/hari, kemudian di kalikan dengan pemisahan timbulan air limbah black water dan grey water, dimana pemisahan timbulan air limbah untuk black water $20 \%$ dan grey water $80 \%$ [15]. Hasil yang didapat untuk black water $50,08 \mathrm{~m}^{3} /$ hari sedangkan untuk grey water sebesar $200,32 \mathrm{~m}^{3} /$ hari. Selanjutnya air buangan tersebut masuk ke dalam STP dengan debit 250,4 $\mathrm{m}^{3} /$ hari, air buangan yang diolah oleh sebesar $80 \%$ sehingga debit yang dapat digunakan untuk air bersih second class sebesar 200,32 $\mathrm{m}^{3} / \mathrm{hari}^{\text {. }}$

Hotel X memiliki sistem konservasi air dalam sistem plambing, ini bertujuan untuk mengetahui besaran air bersih yang berkurang oleh usaha pengurangan penggunaan sumber air utama primer yaitu PDAM dengan memanfaatkan kembali air buangan (black water dan grey water) untuk kebutuhan flushing/penggelontoran [7].

$$
\text { Persentase }(\%)=\frac{200,32 \mathrm{~m} 3 / \mathrm{hari}}{313 \mathrm{~m} 3 / \mathrm{hari}} \times 100=64 \%
$$

Dengan mengetahui Qair buangan yaitu $194 \mathrm{~m}^{3} /$ hari dan air kebutuhan total sebesar $313 \mathrm{~m}^{3} / \mathrm{hari}$ maka efisiensi penerapan water conserve ation dengan menggunakan WAC 3 (daur ulang) yang dipergunakan di Hotel X yaitu sebesar 64\% seperti disajikan pada persamaan 6.

\section{Kesimpulan}

Berdasarkan hasil perencanaan dan perhitungan didapatkan timbulan air buangan di Hotel X sebesar $250,4 \mathrm{~m}^{3} /$ hari dengan grey water yang dihasilkan sebesar $200,32 \mathrm{~m}^{3} /$ hari. Dari total kebutuhan air total yang sebesar $313 \mathrm{~m}^{3} /$ hari. Untuk memanfaatkan air buangan maka dibangun sistem pengolahan air buangan (Sewage treatment plant) kegunaan dari setiap unit ini untuk mengurangi kontaminan yang ada diair buangan dengan mengacu baku mutu yang sudah ditetapkan oleh pemerintah. Air buangan dari pengolahan 
dapat digunakan kembali sebagai air second class yang dapat digunakan untuk flushing /penggelontor di kloset dan urinoir. Air yang dapat dihemat jika menggunakan metode sebesar 64\% Sehingga penggunaan aspek konservasi air WAC 3 (Daur ulang) dapat mengurangi penggunaan air bersih yang bersumber dari PDAM.

\section{Daftar Pustaka}

[1] A.A G.P Widanaputra, Herkulanus Bambang Suprasto, Dodik Aryanto, MM dan Ratna Sari. 2009. Akuntansi Perhotelan Pendekatan Sistem Informasi.Yogyakarta: Graha Ilmu.

[2] Balai Pusat Statistik, Kota Batam Dalam Angka, Kota Batam, 2020.

[3] Anonim, 2020. Perencanaan Teknik Hotel X Kota Batam. Kota Batam.

[4] Metcalf and Eddy, 2003, Wastewater Engineering: Treatment, Disposal, and Reuse, Mc Graw Hill Inc. Newyork.

[5] PT. Adhya Tirta Batam (ATB Batam), 2019. Menjaga Sumber Air Baku untuk Keberlangsungan Masa Depan Batam. Kota Batam.

[6] A. Wahyuni, J. Junianto, "Analisa Kebutuhan Air Bersih Kota Batam Pada Tahun 2025," J. TAPAK (Teknologi Aplikasi Konstruksi. Jurnal Program Studi Teknik Sipil), Universitas Muhammadiyah Metro, Lampung, Vol. 6 (2), 2017.

[7] Green Building Council Indonesia. 2013. Penilaian Bangunan Hijau Untuk Bangunan Baru Versi. 2. Jakarta. Indonesia.

[8] D. Y. Rinka, M. R. Sururi, E. Wardhani, "Perencanaan Sistem Plambing Air Limbah dengan Penerapan Konsep Green Building pada Gedung Panghegar Resort Dago Golf-Hotel \& Spa," J. Reka Lingkungan, Vol. 2 (2), 2014.

[9] A. K. Rahayu, Y. Pratama, A. Nurprabowo, "Perencanaan Sistem Instalasi Plambing Air Bersih dengan Penerapan Alat Plambing Hemat Air Di Rumah Sakit Universitas Sam Ratulangi," J. Serambi Enginering, Vol. 5 (2), 2020.

[10] David, V. V., Pharmawati, K., \& Usman, D. K. (2019). Implementasi konsep konservasi air di Gedung Apartemen X. Jurnal Serambi Engineering, 4 (2).

[11] K. Pharmawati, Nurprabowo, "Perencanaan Konsep Konservasi Air Gedung Universitas Swasta di Wilayah Utara Kota Bandung," J. Sumber Daya alam dan lingkungan, Vol. 7 (3), hal. 124-134, 2020.

[12] Badan Standarisasi Nasional. 2005. Tata Cara Perencanaan Sistem Plambing (SNI03-7065- 2005) Badan Standarisasi Nasional Indonesia.

[13] Badan Standarisasi Nasional. 2015. Sistem Plambing pada bangunan gedung (SNI 8153-2015), Badan Standarisasi Nasional Indonesia.

[14] Peraturan Menteri Pekerjaan Umum dan Perumahan Rakyat. 2017. Permen PUPR Nomor 4 tahun 2017 tentang Penyelenggaraan Sistem Pengelolaan Air Limbah Domestik.

[15] V. L. Cahyadi, Perencanaan Bangunan Instalasi Universitas Indonesia Manajemen Lingkungan, 2012.

[16] Morimura dan Noerbambang, Perancangan dan Pemeliharaan Sistem Plambing Edisi 4, Pradnya Paramita, Jakarta, 2000.

[17] Peraturan Pemerintahan Republik Indonesia Nomor 22 Tahun 2021 Tentang Penyelenggaraan Perlindungan dan Pengelolaan Lingkungan Hidup, Jakarta, Indonesia.

[18] Peraturan Pemeritahan Republik Indonesia Nomor 5 Tahun 2014 Tentang Baku Mutu Air Limbah, Jakarta, Indonesia.

[19] D. F. Sitompul, M. Sutisna, K. Pharmawati, "Pengolahan Limbah Cair Hotel Aston Braga City Walk dengan Proses Fitoremediasi menggunakan Tumbuhan Eceng Gondok," J. Reka Lingkungan, Jurusan Teknik Lingkungan Itenas, Vol. 1(2), 2013.

[20] G. A. Rahmawati, E. Wardhani, L. Apriyanti, "Perencanaan Instalasi Pengolahan Air Limbah Mal X Kota Bandung," J. Serambi Engineering, Vol. 4 (2), hal. 522-531, 2019.

[21] P. S. Komala, S. S. Abuzar, P. M. Dewi, "Perencanaan Sistem Plambing Air Buangan Gedung Rusunawa Mahasiswa Universitas Andalas," J. Serambi Engineering, Vol. 4, Edisi Khusus Oktober, hal. 583-592, 2019.

[22] M. Busyairi, N. Adriyanti, A. Kahar, Nurcahya, Sariyadi, T. D. Hudayana, "Efektivitas Pengolahan Air Limbah Domestik Grey Water Dengan Proses Biofilter Anaerob dan Biofilter Aerob (Studi Kasus: IPAL INBIS Permata Bunda, Bontang)," J. Serambi Engineering, Vol. 5(4), hal. 1306-1312, 2020.

[23] P. S. Komala, Y. Ruslinda, J. Zurienra, "Studi Kuantitas Air Buangan Kampus Universitas Andalas Limau Manis Padang," J. Serambi Engineering, Vol. 5 (2), hal. 1050-1062, 2020. 
[24] Tchobanoglous, G., Burton, F. L., \& Stensel, H. D (2014). Wastewater Engineering Treatment and Resource Recovery 5th. New York : Mc. Graw Hill Education. 